Short communication

\title{
Short-term changes in infiltration between straw mulched and non-mulched soils after wildfire in Mediterranean forest ecosystems
}

\author{
Manuel Esteban Lucas-Borja ${ }^{\mathrm{a}}$, Demetrio Antonio Zema ${ }^{\mathrm{b}, *}$, Bruno Gianmarco Carrà ${ }^{\mathrm{b}}$, \\ Artemio Cerdà ${ }^{c}$, Pedro A. Plaza-Alvarez ${ }^{\mathrm{d}}$, Javier Sagra Cózar ${ }^{\mathrm{d}}$, Javier Gonzalez-Romero ${ }^{\mathrm{d}}$, \\ Daniel Moya ${ }^{\mathrm{d}}$, Jorge de las Heras ${ }^{\mathrm{d}}$ \\ a Departamento de Ciencia y Tecnología Agroforestal y Genética, Universidad de Castilla La Mancha, Campus Universitario s/n, C.P. 02071 Albacete, Spain \\ b Department "Agraria", University "Mediterranea" of Reggio Calabria, Località Feo di Vito, I-89122 Reggio Calabria, Italy \\ c Soil Erosion and Degradation Research Group, Department of Geography, University of València, Blasco Ibànez, 28, E-46010 Valencia, Spain \\ ${ }^{\mathrm{d}}$ Departamento de Producción Vegetal y Tecnología Agraria, Universidad de Castilla La Mancha, Campus Universitario s/n, C.P. 02071 Albacete, Spain
}

\section{A R T I C L E I N F O}

\section{Keywords:}

Soil hydraulic conductivity

Soil water content

Soil temperature

Pinus stands

Forest management

\begin{abstract}
A B S T R A C T
Water infiltration is a basic parameter to understand the hydrological response of semi-arid or arid soils - where runoff generation is dominated by infiltration-excess - subjected to wildfire. To evaluate the hydrological effects of straw application on a sandy loam soil after wildfire, the unsaturated hydraulic conductivity, water content and temperature of mulched and nonmulched (considered as control) soils were monitored throughout eight months. Compared to untreated soils, straw maintained higher temperatures and water contents in mulched plots, but reduced their unsaturated hydraulic conductivity, particularly in the drier season. These results suggest that straw release may lead to a decrease of water infiltration capacity of soils subjected to wildfire, with particular evidence in summer in the case of heavy storm occurrence.
\end{abstract}

\section{Introduction}

Wildfire consumes vegetation and alters the soil physical, chemical, and biological properties (Prats et al., 2016a). This increases soil erosion rates, since enhance raindrop impact and surface wash, and reduce infiltration capacity (Cerdà, 1998; Santana et al., 2014). This is because the post-fire changes in soil hydrology are the key to understand the post-fire restoration; however, the number of the studies analysing the post-fire effects on soils at multi-year scale is larger than short-term research (few months after fire).

Many post-fire stabilization and rehabilitation treatments are used to mitigate the short-term effects on soil degradation (Robichaud et al., 2000). Bioengineering treatments for post-fire soil stabilization are currently being used (Vega et al., 2015). Among these treatments, emergency post-fire activities for soil stabilization, such as mulching and seeding, are considered as a first step in fire affected ecosystems restoration; thus, they are often recommended in severely burned areas to minimize overland flow and erosion risk (Vega et al., 2015).

The application of mulching as a rehabilitation treatment against runoff and soil erosion after fires has been widely tested in Mediterranean areas in recent years (Calvo et al., 2012). This treatment consists of spreading organic material (e.g., wheat straw or woodchips) over soil immediately after a fire and just before the first autumn rainfall. Generally, this practice has obtained satisfactory results, including significant reductions in runoff and soil erosion (Santana et al., 2014), as well documented in different literature studies (e.g., Prosdocimi et al., 2016). In addition, the hydrologic implications of post-fire mulching have been studied across different spatial scales, from laboratory conditions and simulated rainfall to field plots and natural rainfall; these latter experimental conditions are more advisable for the analysis of soil mulching effectiveness at reducing runoff and erosion (Prats et al., 2016b). However, the relative effect of individual factors on the post-fire hydrologic response is still not well understood and may vary between regions, sites, vegetation and soil types (Fernández and Vega, 2016). In particular, the effects of mulching on soil moisture and on water infiltration have not been well-described (Prats et al., 2016a,b). These factors, with particular reference to water infiltration capacity of soils, are of fundamental importance in Mediterranean areas, since infiltration-excess mechanism dominates runoff and erosion generation. In such environmental context, intense storm events in autumn and hot summers with drought risks make these zones prone to post-fire erosion and wildfire occurrence, respectively

\footnotetext{
* Corresponding author.

E-mail address: dzema@unirc.it (D.A. Zema).
} 
(Shakesby, 2011). A decreased infiltration increases overland flow and soil erosion (Robichaud and Waldrop, 1994).

In this study we hypothesize that the application of straw mulching increases infiltration in forest soil subject to wildfire (whose effects have been little examined, Covert, 2010). To support this hypothesis, water content, temperature and hydraulic conductivity of a forest soil treated with straw mulching were monitored at plot scale throughout eight months after a wildfire and compared to untreated soil plots.

\section{Materials and methods}

\subsection{Study area}

The study was carried out in the forest area of Liétor (Castilla LaMancha, SE Spain), semi-arid Mediterranean climate (BSk, according to the Köppen-Geiger classification, Kottek et al., 2006). Average annual rainfall and temperature are $282 \mathrm{~mm}$ and $16^{\circ} \mathrm{C}$, respectively. Elevation ranges between 520 and $770 \mathrm{~m}$ a.s.l. and the orientation of the studied area is W-SW. According to the USDA soil taxonomy (USDA, 1998), soil is classified as Inceptisols and Aridisols and its main texture is sandy loam. Mean stoniness of the area is $30-40 \%$.

The forestland mainly consists of Pinus halepensis $\mathrm{M}$. with a mean tree density of about 500-650 trees ha $^{-1}$ and a tree height between 7 and $14 \mathrm{~m}$. The prevalent shrubs and herbaceous species are Rosmarinus officinalis L., Brachypodium retusum (Pers.) Beauv., Cistus clusii Dunal, Lavandula latifolia Medik., Thymus vulgaris L., Helichrysum stoechas (L.), Stipa tenacissima (L.), Quercus coccifera L. and Plantago albicans L.

\subsection{Experimental design}

The study area was affected in July 2016 by the Sierra de las Quebradas wildfire, which burned about 830 ha of forestland. Soil burn severity, equal for all plots, falls in the high class of the classification proposed by Vega et al. (2013). This method evaluates soil burn severity based on soil chemical and microbiological soil parameters. Immediately after the wildfire, one site of about five hectares, totally covered by Pinus halepensis M. and affected by crown fire (tree mortality of $100 \%)$, was selected. Twelve experimental plots $(20 \times 10 \mathrm{~m}$ each one) were installed in the burned area at a reciprocal distance of $20 \mathrm{~m}$, and with their longest dimension along the maximum slope (between 10 and 25\%). Plots were distributed selecting certain sites characteristics, slopes and aspects to ensure the reciprocal comparability; in more details, the plots were located on the same hillslope (thus, with the same aspect and soil characteristics) and the longitudinal profile was similar among the plots under the same treatment. In September 2016, mulching treatment (henceforth indicated as "mulching", M) was assigned randomly to six replicate plots in the burned area; the remaining plots (six replicates, henceforth "no-mulching", NM) were assumed as control. Mulching consisted of manually spreading straw of barley on the plots at a rate of $200 \mathrm{~g} \mathrm{~m}^{-2}$ (dry weight). This dose was set according to Vega et al. (2014), who achieved a mulch cover of burned plots higher than $80 \%$ in Northern Spain. Initial mulch cover and depth were $95 \%$ of the plot area and $3 \mathrm{~cm}$, respectively. Mulch cover was measured by photographing a $1 \mathrm{~m} \times 1 \mathrm{~m}$ quadrat delimiting a sample of mulched soil in each plot and the image was processed calculating the portion of the area covered by straw.

At five sampling dates (18, 24 November and 21 December 2016, 12 May and 12 July 2017) the soil hydraulic conductivity (henceforth "SHC") was measured in 36 randomly distributed points of both plot types (M and NM), three points per six plots per two treatments. The Mini-Disk Infiltrometer (MDI, Decagon Devices, Inc. Pullman, W.A., 2016) was used, as commonly done for field measurement due to its small size and easy handling (Robichaud et al., 2008a,b). Measurements by MDI were done according to the procedures suggested in its technical manual and by Robichaud et al. (2008a,b), in which more details can be found. To summarise, the surface soil $(1 \mathrm{~cm})$ was removed by a small shovel and a cut was made at a depth of $1 \mathrm{~cm}$, to leave a horizontal and smooth surface for placing MDI.

The volume of water infiltrated in the MDI was recorded every $30 \mathrm{~s}$ for no less than $10 \mathrm{~min}$. The soil hydraulic conductivity was estimated from the measurements by the MDI records, adopting the equations proposed by Zhang (1997). The coefficients required by those equations were estimated for the sandy loam soil of the experimental plots according to the user manual of MDI (Carsel and Parrish, 1988; MDI, Decagon Devices, Inc. Pullman, W.A., 2016).

The actual temperature (henceforth "ST") and water content (henceforth "SWC") of the soil in each experimental plot were continuously measured during the monitoring period by thermocouples and soil water content devices, respectively, placed on the soil surface. The thermocouples and soil water content devices used were connected to a data logger (UX120 4-channel Analog Logger, Onset HOBO, Massachussetts, USA). Then, the monthly average values and standard deviations of mean, maximum and minimum temperatures, and water content were calculated for the $\mathrm{M}$ and NM plots.

A weather station (WatchDog 2000 Series model) was placed close to plots to measure the total daily precipitation, air temperature and rain intensity during the study period. The infiltration tests and the other measurements were done no earlier than five days after the last precipitation event.

Both NM and M soil were characterised before the monitoring period, measuring the main properties according to the common soil analysis methods (see Table 1 for more details).

\subsection{Statistical analyses}

A one-way ANOVA was applied to evaluate the statistical significance of changes in SHC, ST and SWC variables between M and NM plots. Variables were transformed when necessary in order to assume statistical parametric assumptions. Homogeneity of variance and normality of samples were checked by Levene's and Kolmogorov-Smirnov's test, respectively. All the plots were considered spatially independent. Independent Fisher's minimum significant difference test (LSD) was used for post hoc analysis comparisons. A level of significance of $\mathrm{p}<0.05$ was adopted. The statistical analysis was performed using the Stratigraphic Centurion software.

\section{Results and discussions}

The analysis of the soil properties revealed significant differences between M and NM plots for the organic matter content, total nitrogen

Table 1

Main characteristics (mean and standard deviation, $n=36$ ) of soil plots of the experimental site (Liétor, Castilla-La Mancha, Spain).

\begin{tabular}{|c|c|c|c|}
\hline \multirow[t]{2}{*}{ Soil characteristic } & \multicolumn{2}{|l|}{ Treatment } & \multirow{2}{*}{$\begin{array}{l}\text { Soil analytical } \\
\text {-method }\end{array}$} \\
\hline & Mulched (M) & Non-Mulched (NM) & \\
\hline Sand (\%) & $59.68 \pm(1.47) a$ & $52.15 \pm(1.47) b$ & Sieving and \\
\hline Loam (\%) & $31.74 \pm(1.14) \mathrm{a}$ & $32.97 \pm(1.14) \mathrm{a}$ & hydrometer \\
\hline Clay (\%) & $14.58 \pm(0.68) a$ & $8.88 \pm(0.68) \mathrm{b}$ & methods \\
\hline$p H(-)$ & $8.51 \pm(0.02) \mathrm{a}$ & $8.46 \pm(0.02) a$ & measured by the \\
\hline $\begin{array}{l}\text { Electrical } \\
\quad \text { conductivity } \\
(\text { mmhos } / \mathrm{cm})\end{array}$ & $0.28 \pm(0.03) \mathrm{a}$ & $0.19 \pm(0.03) \mathrm{a}$ & $\begin{array}{l}\text { portable meter } \\
\text { "HACH Lange } \\
\text { 40D" }\end{array}$ \\
\hline $\begin{array}{l}\text { Organic matter } \\
\text { content (\%) }\end{array}$ & $10.84 \pm(0.87) a$ & $4.75 \pm(0.87) b$ & $\begin{array}{l}\text { Walkley and Black, } \\
1934\end{array}$ \\
\hline Total nitrogen (\%) & $0.40 \pm(0.02) \mathrm{a}$ & $0.22 \pm(0.02) \mathrm{b}$ & $\begin{array}{l}\text { Nelson and } \\
\text { Sommers, } 1998\end{array}$ \\
\hline $\begin{array}{c}\text { Cation Exchange } \\
\text { Capacity } \\
\text { (cmol/kg) }\end{array}$ & $22.16 \pm(0.90) a$ & $18.11 \pm(0.90) \mathrm{b}$ & $\begin{array}{l}\text { Polemio and } \\
\text { Rhoades, } 1977\end{array}$ \\
\hline
\end{tabular}

Note: Different lower case letters indicate significant differences at $\mathrm{p}<0.05$ level of the LSD test. 


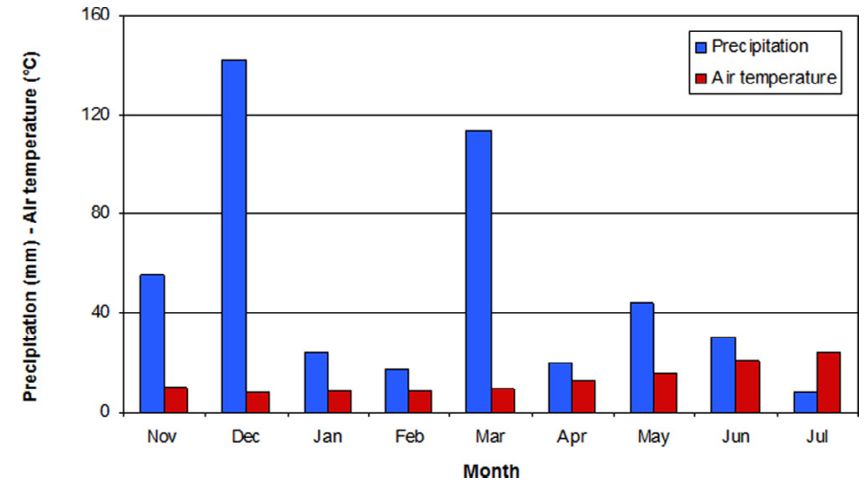

Fig. 1. Mean monthly air temperature and precipitation in the experimental site (Liétor, Castilla-La Mancha, Spain).
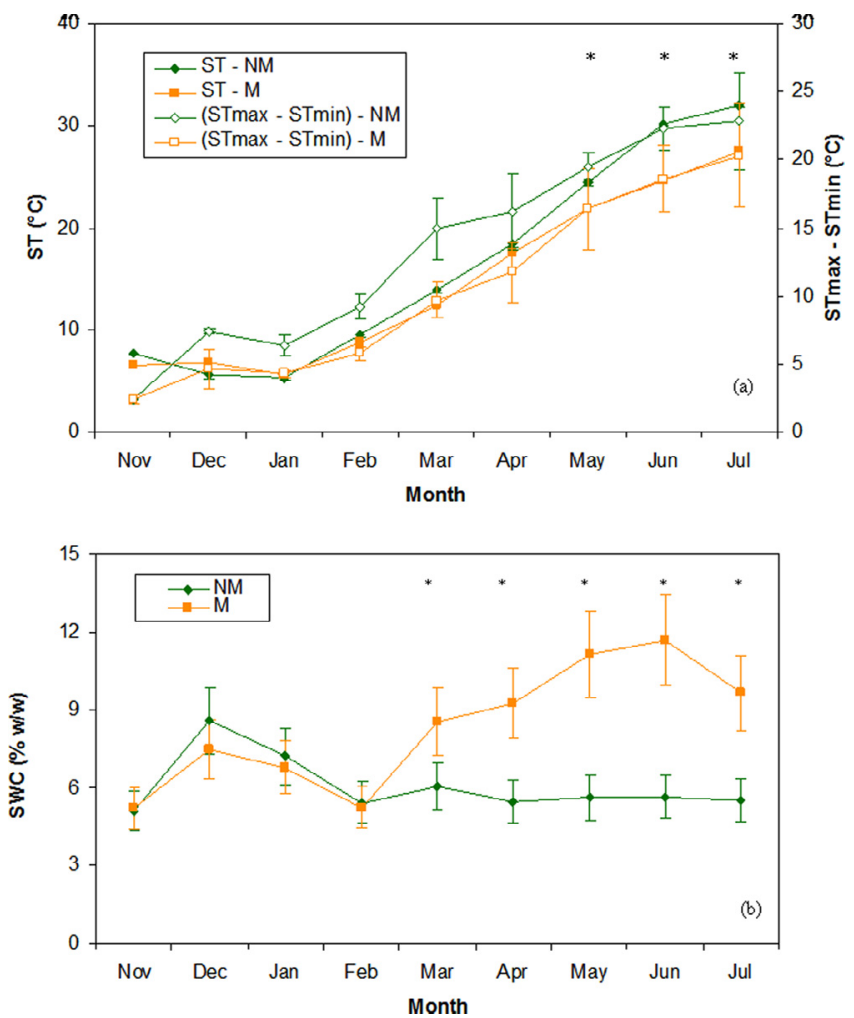

Fig. 2. Mean monthly values (ST) and difference $\left(\mathrm{ST}_{\max }-\mathrm{ST}_{\min }\right)$ of temperatures (a), and water content (SWC, b) of mulched (M) and non-mulched (NM) soil plots of the experimental site (Liétor, Castilla-La Mancha, Spain). Asterisks indicate significant differences between the two treatments at $p<0.05$ level of the LSD test.

and cation exchange capacity; as regards the soil texture, the contents of sand and clay were different, while the loam fraction was practically equal (Table 1).

Mean ST generally followed the air temperature (Fig. 1). ST was almost constant in the wetter months (November to January, on average $6.3^{\circ} \mathrm{C}$ ) and progressively increased in spring, reaching the maximum values in the hotter month (July, on average $29.8^{\circ} \mathrm{C}$ ). In the colder months and in spring (November to April) ST was slightly higher in NM plots compared to $\mathrm{M}$ soils, even though without significant differences between the two soil treatments (mean $\Delta \mathrm{T}=-0.49^{\circ} \mathrm{C}$ ) (Fig. 3a). Conversely, in the late spring-early summer periods (May to July), the mulched soils showed significantly lower ST (on average $\Delta \mathrm{T}=-4.2^{\circ} \mathrm{C}$ ) compared to NM plots. Thus, M soils were colder than NM plots. Also the amplitude of the monthly $\mathrm{ST}\left(\mathrm{ST}_{\max }-\mathrm{ST}_{\min }\right.$ ) was lower in $\mathrm{M}$ plots compared to NM soil, being the mean difference

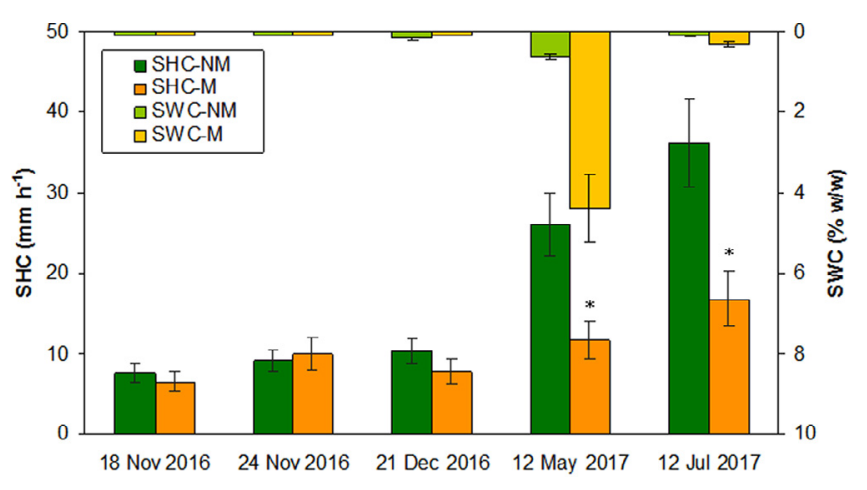

Date

Fig. 3. Isolated measurements of soil hydraulic conductivity (SHC) and daily water content (SWC) of mulched (M) and non-mulched (NM) soil plots of the experimental site (Liétor, Castilla-La Mancha, Spain). Asterisks indicate significant differences between the two treatments at $p<0.05$ level of the LSD test.

between $\mathrm{ST}_{\max }$ and $\mathrm{ST}_{\min }$ of $\mathrm{M}$ plots equal to $3^{\circ} \mathrm{C}-$ similar in the wet and in the dry months - against a value of $6.4^{\circ} \mathrm{C}$ in NM soils (Fig. 2a). This may be due to the shadowing effect played by the straw (Mulumba and Lal, 2008), which was able to reduce both the mean ST and its amplitude of the soil in the treated plots.

SWC followed the precipitation trends (Fig. 1). In NM plots an increase of SWC was recorded in the wettest months, that is in December (142 $\mathrm{mm}$ of precipitation) and in March $(114 \mathrm{~mm})$. In these plots, SWC decreased in the drier months (when monthly precipitation reduced until the minimum value of July, $8 \mathrm{~mm}$ ). Conversely, regardless of the precipitation trends, SWC of the M plots was lower between November and February, generally wet and cold, and higher from March to July (generally drier and warmer) (Figs. 1 and 2b). Deeper investigations are needed to explain this unexpected result (for instance, measures of the enzymatic and biological activity of soil, which, presumably enhanced by the shadowing effect of straw, could have increased its water retention capacity).

M soils generally showed a higher SWC compared to the NM plots. The difference, on average equal to $-0.41 \%$ between November and February, became positive and significant (with a mean value of $4.41 \%$ ) between March and July, in general drier (Fig. 2b). This result is in accordance with the outcomes of Prats et al. (2012, 2016b), who reported that: (i) mulching significantly increased soil moisture content in a burned sandy soil with Eucalypt stands; (ii) during dry periods the mulched plots were wetter than the untreated ones (with the reversed result during wet periods); (iii) there were shifts in the relation between untreated and mulched soil moisture values associated with the dry and wet periods. SWC differences of the monitored plots may be attributable to two reasons: (i) the higher ST of the NM plots, compared to M soils, determined a more intense local evaporation of soil water, which reduced SWC; (ii) the significantly higher organic matter content of the M plots (10.84\% against $4.75 \%$ of the NM soil), which may have increased the water retention capacity of M soils, acting a synergic effect with those of straw.

SHC showed, in general, noticeable variations from the wetter (November-December, on average $9.0 \mathrm{~mm} \mathrm{~h}^{-1}$ ) to the drier (May-July, on average $31.1 \mathrm{~mm} \mathrm{~h}^{-1}$ ) periods in NM soils. Literature reports that the hydraulic conductivity of burned soils worsens immediately after the fire (for instance due to some negative effects, such as the increase of soil water repellency, reduction of soil aggregate stability, burning of the organic matter, Prats et al., 2016a; Santana et al., 2014; Shakesby, 2011). The trend of SHC in the untreated soils of this study showed that this low infiltration capacity tends to recover with time (as reported also, for instance, by Cerdà and Robichaud, 2009). This infiltration capacity recovery in soil is in accordance with Robichaud et al., 2008a,b, 2013, who, using MDI, found low infiltration rates 
immediately post-fire, but higher values of this hydrological parameter one year after the wildfire on a loam soil. Conversely, SHC was almost constant throughout the monitoring period in M plots $\left(6.5-11.7 \mathrm{~mm} \mathrm{~h}^{-1}\right.$ between November to May, with the maximum value recorded in July, $16.8 \mathrm{~mm} \mathrm{~h}^{-1}$ ) (Fig. 3).

The comparison between the two treatments highlighted that the difference in the SHC was significant only in the drier periods (May to July), M plots showing the lower values (on average $14.2 \mathrm{~mm} \mathrm{~h}^{-1}$ against $31.1 \mathrm{~mm} \mathrm{~h}^{-1}$ measured in NM soils in the same months) (Fig. 3). Moreover, the wetter the soil, the higher the SHC: Fig. 3 shows that, when the differences in SWC are significant, also SHC is significantly different between NM and M plots (e.g. surveys made in May and July). In other words, when M plots show significantly higher SWC, they have also significantly lower SHC. These results comply with statements of some authors (e.g. Hillel, 1998), who report that, when the SWC is higher, the SHC decreases and this soil behaviour is more pronounced for sandy loam soils as those of this study. No correlations were found between SHC and SWC $\left(\mathrm{r}^{2}<0.02\right.$ for both M and NM soils).

Overall, the SHC measurements by the tension infiltrometer carried out after wildfire in this study relates to the unsaturated fire-affected soil. This parameter may be initially more important than saturated hydraulic conductivity at the time scale of convective rainfall, which is typically short and only lasts $20-60 \mathrm{~min}$, but common in many postwildfire response domains (Moody et al., 2013). Since this investigation showed that mulched soil may be affected by a lower SHC compared to untreated soils, this treatment must be applied with caution in semiarid or arid Mediterranean forest ecosystems. As a matter of fact, given that in the soils typical of this climatic context (in particular, those of prevalent sandy texture) the Hortonian (that is, infiltration-excess) overland flow type dominates, a reduction of soil infiltration capacity due to straw mulching may worsen their hydrological behaviour, with possible increase of water runoff and soil erosion (Shakesby, 2011); as a matter of fact, Fernández -Fernández et al. (2016) demonstrated that straw mulching may not reduce soil erosion in temperate and moderately rainy climate of the Mediterranean environments. In fact, a lower water infiltration reduces water storage of soil during heavy storms, thus increasing the net precipitation, an important share of which generates surface runoff.

The reduction in SHC detected in the M soils contrasts the working hypothesis of our study, which supposed that the application of straw mulching instead increases infiltration in forest soil after wildfire. This result deserves more investigation: in fact, it is true that mulched soil subjected to wildfire shows negative effects on water infiltration, but, in several environmental contexts and different land uses, mulching has generally been shown to confer several beneficial effects on soil's hydrological properties (e.g., protection against raindrop impact, increase in water storage into soil, reduction of overland flow velocity, improvement of structure and organic matter content, more optimal germination and root development of vegetation, decrease in evaporation) (Prosdocimi et al., 2016). Therefore, future research must investigate the effects of soil mulching on the runoff generation and soil loss with particular attention to the very delicate Mediterranean ecosystems, such as the forests prone to wildfires. An approach dealing with a water balance of soil at plot or hillslope scale is suggested, since it will allow to quantify each component of water cycle (runoff, evapo-transpiration, interception, infiltration) of forested areas.

\section{Conclusions}

This study has evaluated the effects of straw application on a sandy loam soil subject to wildfire on water infiltration capacity. An eightmonth monitoring of the hydraulic capacity, water content and temperature of the mulched soil showed that the unsaturated infiltration may be lower compared to untreated plots, particularly in the drier season. Since water infiltration capacity is a basic parameter in arid and semiarid soils dominated by infiltration-excess runoff generation mechanisms, straw release on soils subject to wildfire can lead to a decrease of hydraulic conductivity, because of the soil water content (increasing its saturation level). This reduction in soil infiltration capacity may be dangerous at the beginning of heavy storms often occurring in semi-arid or arid forests also in the drier season, since it could increase the net precipitation, with a possibility of an enhanced surface runoff generation.

On the whole, the results of this study, targeted to a better understanding of hydrological processes after wildfire, support land managers towards the identification of the most suitable soil conservation practices to mitigate undesirable post-fire responses in Mediterranean forest ecosystems.

\section{References}

Calvo, L., Baeza, J., Marcos, E., Santana, V., Papanastasis, V.P., 2012. Post-fire management of shrublands. In: Moreira, F., Arianoutsou, M., Corona, P., De las Heras, J. (Eds.), Post-fire management and restoration of Southern European forests. Springer, New York, NY, pp. 293-320.

Carsel, R.F., Parrish, R.S., 1988. Developing joint probability distributions of soil water retention characteristics. Water Resour. Res. 24, 755-769.

Cerdà, A., 1998. Changes in overland flow and infiltration after a rangeland fire in a Mediterranean scrubland. Hydrol. Process. 12 (7), 1031-1042.

Cerdà, A., Robichaud, P.R., 2009. Fire Effects on Soils and Restoration Strategies. Science Publishers, Enfield, NH.

Covert, A., 2010. The effects of straw mulching on post-wildfire vegetation recovery in southeastern British Columbia. BC J. Ecosyst. Manage. 11 (3), 1-12.

Fernández, C., Vega, J.A., 2016. Are erosion barriers and straw mulching effective for controlling soil erosion after a high severity wildfire in NW Spain? Ecol. Eng. 87, $132-138$.

Fernández-Fernández, M., Vieites-Blanco, C., Gómez-Rey, M.X., González-Prieto, S.J., 2016. Straw mulching is not always a useful post-fire stabilization technique for reducing soil erosion. Geoderma 284, 122-131.

Hillel, D., 1998. Environmental Soil Physics: Fundamentals, Applications, and Environmental Considerations. Elsevier, Nederland.

Kottek, M., Grieser, J., Beck, C., Rudolf, B., Rubel, F., 2006. World Map of the KöppenGeiger climate classification updated. Meteorol. Z 15, 259-263.

Moody, J.A., Shakesby, R.A., Robichaud, P.R., Cannon, S.H., Martin, D.A., 2013. Current research issues related to post-wildfire runoff and erosion processes. Earth Sci. Rev. 122, 10-37.

Mulumba, L.N., Lal, R., 2008. Mulching effects on selected soil physical properties. Soil Tillage Res. 98 (1), 106-111.

Nelson, D.W., Sommers, L.E., 1998. Total nitrogen analysis for soil and plant tissues. J. Assoc. Off. Anal. Chem. 63, 770-778.

Polemio, M., Rhoades, J.D., 1977. Determining cation exchange capacity: a new procedure for calcareous and gypsiferous soils. Soil Sci. Soc. Am. J. 41, 524-528.

Prats, S.A., MacDonald, L.H., Monteiro, M., Ferreira, A.J., Coelho, C.O., Keizer, J.J., 2012. Effectiveness of forest residue mulching in reducing post-fire runoff and erosion in a pine and a eucalypt plantation in north-central Portugal. Geoderma 191, 115-124.

Prats, S.A., Wagenbrenner, J.W., Martins, M.A., Malvar, M.C., Keizer, J.J., 2016b. Hydrologic implications of post-fire mulching across different spatial scales. Land Degrad. Dev. 27 (5), 1440-1452.

Prats, S.A., Wagenbrenner, J.W., Martins, M.A.S., Malvar, M.C., Keizer, J.J., 2016a. Midterm and scaling effects of forest residue mulching on post-fire runoff and soil erosion. Sci. Total Environ. 573, 1242-1254.

Prosdocimi, M., Tarolli, P., Cerdà, A., 2016. Mulching practices for reducing soil water erosion: a review. Earth Sci. Rev. 161, 191-203.

Robichaud, P.R., Lewis, S.A., Ashmun, L.E., 2008a. New Procedure for Sampling Infiltration to Assess Post-fire Soil Water Repellency. US Department of Agriculture, Forest Service, Rocky Mountain Research Station, Fort Collins, CO Research Note RMRS-RN-33.

Robichaud, P.R., Waldrop, T.A., 1994. A comparison of surface runoff and sediment yields from low- and high-severity site preparation burns. JAWRA J. Am. Water Resour. Assoc. 30 (1), 27-34.

Robichaud, P.R., Beyers, J.L., Neary, D.G., 2000. Evaluating the effectiveness of post-fire rehabilitation treatments. General Technical Report RMRS-GTR-63. US Department of Agriculture, Forest Service, Rocky Mountain Research Station September 2000.

Robichaud, P.R., Lewis, S.A., Ashmun, L.E., 2008b. New procedure for sampling infiltration to assess post-fire soil water repellency. Research Note, RMRS-RN-33. U.S. Department of Agriculture, Forest Service, Rocky Mountain Research Station, Fort Collins, CO.

Robichaud, P.R., Jordan, P., Lewis, S.A., Ashmun, L.E., Covert, S.A., Brown, R.E., 2013. Evaluating the effectiveness of wood shred and agricultural straw mulches as a treatment to reduce post-wildfire hillslope erosion in southern British Columbia, Canada. Geomorphology 197, 21-33.

Santana, V.M., Alday, J.G., Baeza, M.J., 2014. Mulch application as post-fire rehabilitation treatment does not affect vegetation recovery in ecosystems dominated by obligate seeders. Ecol. Eng. 71, 80-86.

Shakesby, R.A., 2011. Post-wildfire soil erosion in the Mediterranean: review and future research directions. Earth Sci. Rev. 105 (3-4), 71-100.

USDA, N., 1998. Keys to soil taxonomy. USDA, Washingt. DC Google Sch. 
Vega, J.A., Fontúrbel, M.T., Merino, A., Fernández, C., Ferreiro, A., Jiménez, E., 2013. Testing the ability of visual indicators of soil burn severity to reflect changes in soil chemical and microbial properties in pine forests and shrubland. Plant Soil 369, 73-91.

Vega, J.A., Fernández, C., Fontúrbel, M.T., González-Prieto, S.J., Jiménez, E., 2014. Testing the effects of straw mulching and herb seeding on soil erosion after fire in a gorse shrubland. Geoderma 223-225, 79-87.

Vega, J.A., Fernández, C., Fonturbel, T., 2015. Comparing the effectiveness of seeding and mulching + seeding in reducing soil erosion after a high severity fire in Galicia (NW Spain). Ecol. Eng. 74, 206-212.

Walkley, A., Black, I.A., 1934. An examination of the Degtjareff method for determining soil organic matter, and a proposed modification of the chromic acid titration method. Soil Sci. 37 (1), 29-38.

Zhang, R., 1997. Determination of soil sorptivity and hydraulic conductivity from the disk infiltrometer. Soil Sci. Soc. Am. J. 61, 1024-1030. 